\title{
PENERIMAAN DIRI REMAJA YANG MEMILIKI KELUARGA TIRI
}

\author{
Fatihul Mufidatu Z, \\ Yulia Sholichatun, \\ sholihah.y@gmail.com \\ Fakultas Psikologi \\ Universitas Islam Negeri (UIN) Maulana Malik Ibrahim Malang
}

\begin{abstract}
Abstrak - Penerimaan diri merupakan kondisi ketika seseorang mampu menerima segala aspek tentang dirinya tanpa membenci dirinya sendiri. Penerimaan diri menjadi sangat sulit di masamasa remaja dan membutuhkan dukungan dari keluarga. Namun pembentukan keluarga baru dapat membuat remaja mengalami kesulitan yang lebih dalam untuk menumbuhkan penerimaan dirinya. Penelitian ini bertujuan untuk mendeskripsikan penerimaan diri remaja yang memiliki keluarga tiri serta mengetahui faktor-faktor yang menunjang penerimaan diri remaja yang memiliki keluarga tiri. Metode yang digunakan dalam penelitian ini adalah kualitatif dengan disain studi kasus. Proses pengambilan data dilakukan dengan observasi partisipan dan juga wawancara mendalam. Subjek dalam penelitian ini adalah remaja laki-laki dan perempuan yang memiliki keluarga tiri. Hasil analisis penelitian menunjukkan bahwa kedua subjek yang memiliki keluarga tiri memiliki penerimaan diri yang berbeda meskipun keduanya sama-sama mendapatkan penolakan dari keluarga tirinya. Subjek perempuan memiliki penerimaan diri yang baik sementara itu subjek laki-laki kurang memiliki penerimaan diri. Usia dan jenis kelamin subjek menjadi faktor yang berperan. Faktor lain yang juga mendukung penerimaan dirinya adalah dukungan sosial, berfikir positif, pemahaman diri, konsep diri positif, memiliki keberhasilan dalam bidang tertentu, harapan realistis, serta tidak memiliki stress yang berat.
\end{abstract}

Kata kunci: penerimaan diri, remaja, keluarga tiri

PSIKOISLAMIKA. Jurnal Psikologi Islam (JPI) copyright (c) 2016 Pusat Penelitian dan Layanan Psikologi. Volume 13. Nomor 1, Tahun 2016

\section{PENDAHULUAN}

Ketidakmatangan dalam hubungan keluarga pada masa remaja merupakan bahaya psikologis karena pada saat remaja lah anak laki-laki dan perempuan merasa sangat tidak percaya diri sehinga membutuhkan dorongan dan perlindungan dari pihak keluarga (Hurlock, 1980). Keluarga merupakan satu unit terkecil yang pertama kali dikenal oleh anak. Keluarga memiliki peranan yang sangat penting untuk kelangsungan hidup anak, mulai dari menyediakan rasa aman hingga membentuk karakter diri anak.

Arti keluarga untuk anak sendiri juga sangatlah penting, karena selain memberikan jaminan pertumbuhan fisik kepada anak, keluarga juga memegang tanggung jawab yang penting bagi perkembangan mental anak (Notosoedirdjo \& Latipun, 2007). Dalam lingkup kehidupan anak keluarga mempunyai tugas meneruskan norma-norma dan budaya hidup. Dalam sosialisasi domestic atau sosialisasi yang terjadi dalam lingkungan keluarga anak dapat mengenal akan dirinya sendiri, siapa dia, serta bagaimana dia mengadakan suatu konsepsi diri dan mengenal apa yang dia mampu dan dia tidak mampu lakukan serta turut serta dalam pembentukan kepribadian anak (Notosoedirdjo dan Latipun, 2007). Dengan tugas yang diemban oleh keluarga tersebut sangatlah sulit jika hanya dijalankan oleh keluarga yang tidak memiliki anggota lengkap didalamnya 
yang berperan sebagai ayah maupun ibu. Dengan hanya satu orang tua saja dapat menyebabkan tugas yang dimiliki oleh keluarga tidak dapat secara sempurna disampaikan kepada anak.

Pengaruh rumah tangga yang pecah terhadap hubungan keluarga tergantung dari faktor yang menyebabkannya, bisa berupa kematian, maupun perceraian. Perpisahan yang disebabkan perceraian cenderung membuat anak dinilai berbeda oleh kelompok teman sebayanya. (Hurlock, 1978). Beberapa anak tidak bisa terbebas dari dampak perceraian orang tua mereka. Perasaan terluka, marah, terabaikan dan tidak dicintai terus menetap di hati mereka bahkan sampai anak-anak menjadi dewasa (Cole, 2004:3). Belum lagi jika orang tua tersebut memutuskan untuk menikah lagi (remarriage) dengan orang lain dimana anak dipaksa untuk menerima kehadiran orang baru yang harus mereka akui sebagai orang tua mereka.

Perkawinan lagi (remarriage) adalah salah satu cara yang dipilih oleh orang dewasa dalam upaya pemecahan sebagian besar masalah mereka akibat perceraian yang terjadi. Dalam perkawinan lagi (remarriage) penyesuaian diri yang harus dilakukan baik oleh pihak wanita maupun laki-laki terbilang lebih sulit jika dibandingkan dengan penyesuaian diri yang harus dilakukan ketika pernikahan pertama. Apabila salah satu atau bahkan kedua belah pihak sudah memiliki anak dari pernikahan sebelumnya, maka penyesuaian diri akan menjadi lebih sulit bukan hanya untuk orangtua yang menikah kembali, melainkan juga untuk anak mereka (Hurlock, 1980).

Apabila kondisi tersebut terjadi, orang tua memiliki tugas dalam mengantisipasi reaksi anak terhadap orang tua tiri baru dan memutuskan peran orang tua tiri tersebut dalam keluarga. Transisi ke keluarga baru merupakan hal yang sulit bagi siapapun terutama bagi anak yang telah menderita akibat perceraian yang terjadi antara orang tuanya (Cole, 2004).

Santrock (2007:36) berpendapat keberhasilan penyesuaian diri anak dengan orangtua tiri sangat dipengaruhi oleh tingkat usia anak pada waktu remarriage dilangsungkan. Masa remaja awal merupakan suatu masa yang sulit untuk membentuk keluarga tiri. Hal tersebut karena lingkungan keluarga tiri memperburuk kekhawatiran remaja tentang identitas, otonomi, dan seksualitas. Sedangkan Hurlock (1980) berpendapat anak yang lebih dewasa sudah memiliki pola hidup tertentu yang akan cenderung menolak terhadap setiap unsur yang akan mengubah pola hidup yang sudah dibentuknya, terutama bila dalam dirinya telah berkembang sikap yang tidak senang terhadap orangtua tiri. Sebaliknya, anak-anak yang lebih muda dapat menyetujui kehadiran orangtua tiri (Hurlock, 1980).

Anak-anak jarang memandang orang tua tiri sebagai orang tua yang sebenarnya karena biasanya anak-anak mempertahankan kesetiaan yang kuat terhadap orang tua biologis mereka, (Hurlock, 1980). Hal tersebut sejalan dengan temuan peneliti yang didapatkan melalui wawancara dengan remaja yang memiliki orangtua tunggal. Subjek mengaku tidak setuju jika orang tua mereka menikah lagi dengan orang lain, bahkan mereka lebih memilih diasuh hanya oleh orangtua tunggal daripada harus dengan orangtua tiri.

Ketika anak memasuki usia remaja maka akan sangat sulit untuk membuatnya tetap baikbaik saja dalam kehidupannya dengan keluarga tiri sebagaimana yang ditunjukkan oleh hasil penelitian Yurika (2014). Penelitian yang berjudul Pencapaian Identitas Remaja yang Memiliki Ibu Tiri menyimpulkan bahwa pencapaian identitas remaja yang memiliki ibu tiri adalah kurang baik (Yurika, 2014). Namun menurut Hurlock (1978) pencapaian identitas diri yang kurang baik dapat dicegah jika remaja memiliki penerimaan diri yang baik. Semakin banyak orang yang menyukai dan menerima mereka, maka remaja akan semakin senang dengan dirinya sendiri serta semakin kuat menerima dirinya yang hal tersebut dapat menunjang penyesuaian pribadi dan sosial yang baik.

Penerimaan merupakan dasar bagi setiap orang untuk dapat menerima kenyataan dalam hidupnya dari mulai pengalaman yang baik maupun pengalaman yang buruk. Penerimaan ditandai dengan adanya sikap yang positif, adanya pengakuan atau penghargaan terhadap nilai-nilai individual tetapi menyertakan pengakuan terhadap tingkah lakunya. (Kubler Ross, 1998) Penerimaan merupakan salah satu karakteristik yang dimiliki oleh orang yang memiliki kepribadian yang sehat. Dimana dari penerimaan itu sendiri terdapat beberapa jenis, mulai dari penerimaan terhadap kenyataan, penerimaan terhadap tanggung jawab, penerimaan sosial, penerimaan dalam control emosi. (Hurlock, 1992).

Jersild (dalam Hurlock, 1973; 1976) menegaskan bahwa orang yang memiliki penerimaan diri akan memiliki penilaian yang realistis terhadap dirinya sendiri, memiliki apresiasi yang positif tentang dirinya sendiri, yakin dengan dirinya sendiri tapa 
terpengaruh oleh pendapat orang lain, memiliki penilaian yang realistis terhadap keterbatasan yang dimiliki olehnya, serta menerima kekurangan mereka tanpa menyalahkan diri mereka sendiri atas kekurangan tersebut. Orang yang menerima dirinya juga akan menghormati dirinya sendiri dan menjalani hidup yang nyaman dengan kondisi dirinya, mampu mengenali keinginannya, harapan, ketakutan dan permusuhan, serta cenderung untuk menerima kondisi emosionalnya dalam arti memiliki kebebasan untuk menyadari sifat perasaannya, lebih bebas untuk menentukan pilihannya sendiri, serta memiliki rasa tanggung jawab.

Menurut Schultz (1991) dalam bukunya mengungkapkan bahwa orang yang menerima dirinya akan menerima kelemahan-kelemahan dan kekuatan-kekuatan mereka tanpa keluahan atau kesusahan. Meskipun mereka memiliki kelemahankelemahan atau cacat-cacat, tetapi mereka tidak merasa malu atau merasa bersalah terhadap halhal tersebut. Mereka menerima kodrat mereka sebagaimana adanya.

Penerimaan diri merupakan sebuah sikap seseorang menerima dirinya sendiri. Penerimaan diri tersebut didasarkan pada pujian yang relatif objektif terhadap talenta-talenta kemampuan dan nilai umum yang unik dari seseorang, sebuah pengakuan yang realistik terhadap keterbatasan dan sebuah rasa puas yang penuh akan talenta maupun keterbatasan dirinya (Reber Arthur \& Reber Emiliy, 2012).

Menurut Sheerer (Dalam Puspitasari, 2002) terdapat beberapa komponen dalam penerimaan diri, komponen-komponen tersebut adalah memiliki keyakinan akan kemampuan dirinya dalam menjalani kehidupan, menganggap dirinya berharga sebagai seorang manusia yang sederajat dengan individu lain, menyadari dan tidak merasa malu akan keadaan dirinya, menempatkan dirinya sebagaimana manusia yang lain sehingga individu lain dapat menerima dirinya, bertanggung jawab atas segala perbuatannya, menerima pujian dan celaan atas dirinya secara objektif, mempercayai prinsip-prinsip atau standard hidupnya tanpa harus diperbudak oleh opini orang lain serta tidak mengingkari atau merasa bersalah atas dorongan-dorongan dan emosi-emosi yang ada pada dirinya.

Kebanyakan dari remaja akan menolak dirinya daripada menerima dirinya, khususnya remaja lakilaki yang masih menginjak pada awal-awal usia remaja (Hurlock, 1973). Remaja yang menerima dirinya akan secara secara realistis menggunakan potensi mereka untuk belajar dan tumbuh serta memiliki kekayaan. Dalam dunia mereka dimana mereka memiliki sedikit bakat namun secara terus terang bisa mengapresiasi apa yang telah mereka raih daripada orang lain yang telah diberkahi segalanya secara berlimpah namun masih tetap menyesali keadaan mereka dan belum menerima diri mereka. Remaja yang memiliki penerimaan diri akan bisa mengenali kemahiran mereka, dan dengan bebas menggambarkan diri mereka meskipun pada kenyataannya tidak semua dari mereka diinginkan. Mereka juga mengenali kelemahan mereka tanpa penyesalan yang sia-sia (Jersild, Brook J. \& Brook D. 1978).

Tinggi rendahnya penerimaan diri remaja ditentukan oleh seberapa besar mereka bisa melakukan penyesuaian diri. Tidak satupun orang bisa berharap memiliki peneyesuaian diri yang baik jika jika dia tidak menyukai dirinya sendiri atau menolak diri. Di sisi yang lain, untuk mendapatkan penerimaan dari orang lain seseorang cenderung untuk berperilaku sedemikian rupa agar orang lain menyukainya, hal tersebut juga dapat meningkatkan penerimaan diri seseorang (Hurlock, 1973).

Penerimaan diri mencapai titik terendah selama rentang kehidupan masa remaja, begitu pula dengan hubungan keluarga dan sosial mencapai titik terendah ketika masa remaja. Remaja membutuhkan perhatian yang lebih dari pihak keluarga dalam menghadapi perubahan-perubahan yang harus diterimanya ketika masa remaja. Apabila remaja memiliki pendapat buruk tentang diriya, maka ia akan belajar untuk menolak dirinya. Jika remaja merasa tidak dicintai dan tidak diinginkan oleh orangtua mereka maka lambat laun mereka akan menumbuhkan konsep diri yang negatif sehingga penerimaan dirinya juga akan terancam. Hal tersebut sejalan dengan pendpaat Hurlock (1978) bahwa penerimaan diri sangat bergantung dari konsep diri yang dimiliki oleh individu.

Pengaruh relasi anak dengan orangtua tiri terhadap penerimaan diri juga ditunjukkan oleh penelitian yang berjudul Hubungan Orang tuaanak, Penerimaan Diri, dan Keputusasaan pada Remaja dari Keluarga Broken Home. Penelitian ini menggunakan 150 responden remaja dari keluarga broken home yang terbagi dalam dua jenis, yakni remaja dengan orang tua bercerai dan remaja dengan keluarga disharmonis. Berdasarkan penelitian tersebut menunjukkan bahwa hubungan orang tua, anak, dan penerimaan diri berpengaruh secara signifikan terhadap keputusasaan pada remaja 
dengan keluarga broken home (Ariani, 2012 ). Hasil penelitian Ariani ini berarti membuktikan bahwa kondisi keluarga yang bercerai maupun disharmoni berpengaruh secara negative terhadap penerimaan diri remaja.

Fenomena sebagaimana hasil penelitian di atas juga ditemukan oleh peneliti terhadap responden penelitian ini. Subjek pertama yakni AC, ia memiliki keluarga tiri yang ia pun juga tinggal satu rumah dengan keluarga tirinya. Subjek ini sudah dapat menerima keadaan keluarga tirinya yang sudah tinggal bersamanya selama kurang lebih 10 tahun setelah melewati proses 3 tahun untuk bisa menerimanya. Berdasarkan penuturan kerabat dekatnya, perilaku AC menunjukkan bahwa subjek sendiri pun sudah menerima keluarganya meskipun menurutnya ia kerap mendapat perlakuan yang kurang baik dari keluarga tirinya bahkan semenjak ia masih berusia 6 tahun. Meskipun sudah 10 tahun mendapatkan perlakuan yang tidak baik dari keluarga tirinya subjek tidak tumbuh menjadi remaja yang membantah dan menolak keluarga tirinya tersebut. Sebaliknya, subjek tumbuh menjadi remaja yang patuh dan bertanggung jawab terhadap perilakunya. Bahkan ketika tengah berbincang-bincang subjek masih berusaha untuk menutupi penolakan yang dilakukan oleh keluarga tirinya, meskipun pada kenyataannya keluarga tirinya masih memperlakukannya dengan tidak baik sebagaimana penuturan kerabat dekatnya.

Responden kedua yakni HD merupakan seorang anak remaja laki-laki yang telah 6 tahun tinggal bersama keluarga tirinya. Ibunya telah menikah lagi dengan seorang laki-laki. Namun interaksi antar anggota dalam keluarga tiri terjadi tidak begitu lancar. HD belum bisa menyesuaikan dirinya dengan keluarga barunya dan juga belum bisa menerima sosok orang yang mau tidak mau harus ia anggap sebagai ayahnya tanpa mengesampingkan ayah kandungnya. Berdasarkan pada ungkapan subjek dan juga orang terdekat subjek pun perilaku tersebut muncul karena subjek sendiri mendapatkan penolakan dari keluarga tirinya sehingga subjek pun kemudian juga menolak keluarga tirinya.

Subjek HD yang sekarang duduk di bangku kelas 1 Sekolah Menengah Pertama sudah mendapatkan penolakan dari ayah tirinya semenjak dia duduk di bangku kelas 1 Sekolah Dasar dimana saat itulah ibu kandungnya resmi menjadi istri dari ayah tiri yang sekarang disapanya Om tersebut. Penolakan yang didapatkannya tersebut menyebabkan ia menolak ayah tirinya. Dalam kesehariannya subjek seringkali mengucapkan kata-kata kotor, membentak ibu kandung dan kakak kandungnya. Bahkan ketika peneliti mencoba untuk membicarakan tentang ayah tirinya tersebut dia secara terang-terangan dan tegas menolak ayah tirinya tersebut dengan berkata "Bukan ayahku"

Dua fenomena berbeda pada anak yang sama-sama tinggal bersama tiri menunjukkan penolakan keluarga tiri terhadap masing-masing subyek ternyata memberikan dampak yang berbeda terhadap penerimaan diri mereka. Bertolak dari hal tersebut maka peneliti tertarik untuk meneliti bagaimana proses penerimaan diri remaja yang memiliki keluarga tiri serta faktor apa saja yang mempengaruhi pembentukan penerimaan diri remaja tersebut.

\section{METODE}

Metode yang digunakan dalam penelitian ini adalah kualitatif dengan disain studi kasus. Subyek penelitian ini terdiri dari subjek penelitian yang menjadi informan kunci yang dapat memberikan data yang dibutuhkan oleh peneliti, yakni satu remaja perempuan dengan inisial $A C$ yang duduk di bangku kelas XI Sekolah Menengah Atas, dan satu remaja laki-laki berinisial $\mathrm{HD}$ yang duduk di bangku kelas VII Sekolah Menengah Pertama. Adapun subjek skunder terdiri dari 3 orang kerabat dekat subyek HD dan 3 orang kerabat dekat subyek AC.

Data penelitian dikumpulkan dengan wawancara. Selanjutnya hasil penelitian dianalisis dengan pendekatan kualitatif model interaktif sebagaimana diajukan oleh Miles dan Hubermas, yaitu terdiri dari empat hal utama, yakni pengumpulan data, reduksi data, pemaparan data dan penarikan kesimpulan atau verifikasi (Sugiyono, 2009).

\section{HASIL PENELITIAN}

Hasil penelitian menunjukkan bahwa dari kedua subjek penelitian sama-sama mendapatkan penolakan dari keluarga tirinya. Jika subjek AC mendapatkan penolakan dari nenek tiri beserta saudara tirinya, subjek HD mendapatkan penolakan dari ayah tiri dan juga diabaikan oleh ibu kandungnya sendiri. Subjek AC kerapkali menerima tugas rumah tangga yang dibebankan oleh keluarga tirinya kepadanya, sedangkan kakak tirinya terbebas dari tugas tersebut. Tak jarang pula ia dimarahi oleh keluarga tirinya tanpa alasan yang jelas. Selain itu keluarga tirinya juga melarangnya untuk mengembangkan bakat yang dimilikinya. la kerapkali mencuci bahkan menyeterika baju milik kedua saudara tirinya, bahkan tidak jarang ia harus mengerjakan tugas milik 
kakak tirinya sementara kakak tirinya tersebut pergi jalan-jalan. Sementara penolakan yang didapatkan oleh subjek HD adalah ayah tirinya secara terangterangan berperilaku menolaknya dengan tidak mau melihat bahkan akan marah jika ia berada dirumahnya sehingga ibu dari subjek kedua sendiri pun memilih untuk menitipkan pengasuhannya kepada tetangganya.

Penolakan yang didapatkan oleh keduanya sama-sama memiliki rentang waktu yang lama. Subjek AC mendapatkan penolakan dari keluarga tirinya selama 11 tahun, sementara itu subjek HD mendapatkan penolakan semenjak ia juga masih duduk di bangku kelas 1 Sekolah Dasar juga mengalami penolakan oleh ayah tirinya selama 6 tahun.

Penolakan yang diterima keduanya memberikan efek secara psikis. Subjek AC menyatakan ia sering merasa sedih dengan penolakan tersebut sedangkan subjek HD merasa benci kepada ayah tirinya karena ia merasa ditolak. Subjek HD juga takut pada ayah tirinya, tidak menyukai diri sendiri, kurang kontrol emosi dan hal-hal yang menjadi tanggungjawabnya kurang mampu dilakukan dengan baik.

Meskipun sedih, subjek AC yang memiliki usia lebih tua daripada subjek kedua mampu untuk berfikir positif sehingga penolakan yang didapatkannya ia anggap sebagai takdir yang harus dijalaninya sehingga ia bisa mengambil hikmah dari perlakuan keluarga tirinya tersebut. Sementara subjek kedua yang masih menginjak awal usia remaja cenderung mengedepankan emosi sehingga ia mersepon penolakan ayah tiri dengan menolak ayah tirinya bahkan tidak perduli terhadap ibu kandungnya sendiri. Penolakan tersebut sangat sulit diterima oleh kedua subyek. Subyek AC membutuhkan waktu selama kurang lebih 3 tahun untuk bisa terbiasa dengan perlakuan nenek dan saudara tirinya. Sementara itu subyek HD yang sudah 6 tahun menerima penolakan dari ayah tirinya masih belum menerima secara penuh terkait penolakan yang didapatkannya.

Proses penerimaan subyekAC terhadap kondisinya yang ditolak oleh keluarga tirinya tidak lepas dari sikap sabar dan berifikir positif yang selalu dilakukannya. AC memilih untuk bersabar menghadapi perlakuan tersebut daripada mengadu kepada ayah kandungnya yang telah tinggal terpisah darinya. la menganggap bahwa perlakuan penolakan yang didapatkannya merupakan takdir yang harus dijalaninya dan juga ia bisa mengambil sisi positif atau hikmah dari kejadian yang menimpanya sehingga ia bisa menerima keadaannya tersebut. Selain itu penerimaannya juga didukung oleh dukungan teman-temannya pada waktu itu ketika ia masih duduk di bangku kelas 3 Sekolah Dasar.

Sementara itu penerimaan subyek HD terhadap kondisinya terlihat sangat sulit karena meskipun sudah 6 tahun ia mendapatkan penolakan dari ayah tirinya. Meskipun beberapa waktu terakhir ayah tirinya sudah tidak lagi terlalu menolak kehadirannya, namun ia masih belum bisa menerima kondisi tersebut dan masih menyimpan amarah dengan keluarganya. la sejak kecil tinggal di bawah pengasuhan orangtua asuhnya dan mendapatkan kasih sayang yang tidak ia dapatkan dari ibu kandung dan juga ayah tirinya.

Dapat disimpulkan bahwa proses penerimaan $\mathrm{HD}$ terhadap kondisi yang dijalaninya didukung oleh keluarga asuhnya. Kurangmampunya ia menerima dirinya sendiri dan juga menerima keadaannya yang ditolak oleh keluarganya juga dipengaruhi oleh lingkungan sekitarnya yang membentuk perilakunya. Sudah 6 tahun ia mendapatkan penolakan dari keluarganya namun ia sendiri masih belum bisa menerima kenyataan tersebut. Perilaku menolaknya semakin diperkuat dengan adanya keluarga asuhnya yang terkadang secara tidak langsung membentuk kepribadiannya untuk menolak keadaannya tersebut.

Salah satu faktor penting dalam penerimaan diri adalah tidak adanya stress emosi yang berat. Memang benar baik subjek AC maupun subjek HD mendapatkan penolakan dari keluarga tirinya, namun hal tersebut tidak membuat mereka memiliki stress emosi yang berat. Keduanya memiliki cara sendiri untuk menerima keadaan tersebut hingga tidak lagi menjadi bahaya bagi penerimaan diri mereka. Subjek $\mathrm{AC}$ dengan lapang dan berebesar hati menganggap bahwa penolakan yang ia dapatkan adalah takdir yang harus ia jalani, sehingga hal tersebut menjadi kekuatannya sendiri untuk mampu menerima dan menjalani kehidupannya yang ditolak oleh keluarga tirinya dengan sabar. Sementara subjek kedua yang diliputi oleh kebencian memilih untuk mengabaikan keluarga kandungnya dengan beralih kepada keluarga asuhnya yang lebih menyayanginya daripada keluarga kandungnya.

Dukungan sosial dari keluarga asuh yang diterima oleh subjek kedua dapat membantunya dalam memunculkan penerimaan dirinya meskipun masih dalam kadar yang sedikit, sementara subjek pertama yang bahkan tidak mendapatkan dukungan sosial memilih untuk selalu berfikir positif terhadap kejadian yang menimpanya sehingga ia bisa melewati hal tersebut dengan mudah. 
Perbedaan usia dan jenis kelamin diantara kedua subjek juga berperan terhadap penerimaan diri yang mereka miliki. Berdasarkan pada penelitian yang telah dilakukan dapat diketahui bahwa meskipun kedua subjek mengalami perilaku penolakan dari keluarga tirinya subjek pertama memiliki penerimaan dan penerimaan diri yang lebih baik jika dibandingkan dengan subjek kedua. Subjek pertama mengedepankan sikap sabar dan berfikir positif dalam menerima setiap kejadian yang menimpanya sehingga ia lebih mudah dalam penyesuaian diri dan tidak terpuruk dalam kesedihan.

\section{DISKUSI}

Hasil penelitian ini menunjukkan adanya penolakan yang dialami oleh kedua subyek dari keluarga tiri masing-masing. Hurlock (Silalahi, 2010) mengungkapkan bahwa perilaku penolakan yang diberikan oleh orangtua terhadap anaknya adalah pengabaian kesejahteraan anak, atau dengan menuntut terlalu banyak dari anak, serta sikap bermusuhan yang terbuka. Sukmawati (Silalahi, 2010) memperjelas bahwa sikap penolakan orang tua terhadap anaknya dapat dimanifestasikan dalam beberap cara, seperti melalaikan dalam perawatan fisik, penolakan afeksi, tidak memberikan dorongan dan perhatian untuk berprestasi, perlakuan yang kasar terhadap anak, hukuman yang terlalu berat bagi kesalahan-kesalahan kecil, dan tidak memperdulikan perasaan anak.

Perilaku penolakan yang diterima kedua subjek memberikan efek baik secara psikis. Subjek AC sering mengalami perasaan sedih dan subjek HD membenci dan takut pada ayah tirinya, sulit mengontrol emosi dan kepercayaan dirinya rendah. $\mathrm{Hal}$ ini sejalan dengan pendapat Fahmi (Silalahi, 2010) bahwa penolakan dari orangtua tehadap anak akan menimbulkan masalah yang serius terhadap tumbuh kembang anak baik secara psikis maupun fisik, karena pada masa remaja lah anakanak merasa sangat membutuhkan dukungan dari orangtua mereka untuk menyesuaikan diri dengan lingkungan baru dan juga dengan perubahan fisiknya. Sementara itu penolakan yang dilakukan oleh orangtua dapat menyebabkan anak berperilaku agresif dan menentang, selain itu juga dapat menyebabkan anak melakukan hal-hal yang berbahaya untuk menarik perhatian kedua orangtuanya, selain itu anak dapat mengembangkan konsep diri yang buruk terhadap dirinya serta menolak dirinya sendiri.

Penolakan yang dilakukan oleh orangtua bisa menuntun anak untuk menolak dirinya sendiri. Rogers
(Hall \& Lindzey, 1985) mengungkapkan bahwasannya kendati penolakan sudah tidak diperlihatkan oleh anak namun perasaan tersebut masih tetap ada dan masih tetap mempengaruhi perilaku mereka meskipun mereka tidak sadar. Jika nilai kebenaran terus digantikan oleh nilai yang diambil dari orang lain maka kepribadian akan terbagi menjadi beberapa bagian. Dan mereka akan merasa jika mereka tidak benar-benar mengetahui siapa mereka dan apa yang mereka inginkan.

Proses penerimaan diri kedua subjek telah berlangsung cukup lama. SubjekAC sudah mengalami penolakan selama 10 tahun dengan hasil mampunya AC menerima kondisinya, sedangkan subjek HD telah mengalami penolakan selama 6 tahun namun belum juga mampu menerima kondisinya. Menurut Kubler Ross (Fahrani, 2014) sebelum seseorang bisa menerima keadaannya maka orang tersebut setidaknya melalui 5 (lima) tahapan penerimaan, tahapan tersebut adalah tahap penolakan dimana setiap orang akan menolak keadaannya dan menyalahkan kondisinya, sementara itu tahap kedua adalah tahap marah dimana kebanyakan individu akan marah dan benci terhadap dirinya maupun kondisinya, tahap ketiga adalah tahap tawarmenawar dimana individu mulai berdialog dengan perasaannya, tahap keempat adalah tahap deperesi dimana individu akan berduka dan mulai memahami kondisinya namun belum cukup termotivasi, tahap terakhir adalah tahap penerimaan dimana individu mulai menerima segala sesuatu dalam diri maupun kondisi yang dilaluinya.

Sementara itu menurut penelitian yang dilakukan oleh Fahrani (2014) bahwa penerimaan remaja yang memiliki ibu tiri dibagi menjadi tiga kategori dimana kategori pertama adalah remaja yang pada awal menolak ibu tiri namun seiring berjalannya waktu dapat menerima kehadiran ibu tiri, kedua yakni remaja yang sejak awal memiliki ibu tiri belum mampu menerima kehadiran ibu tiri, dan yang ketiga yakni remaja yang sedari awal memiliki hubungan yang baik dengan ibu tiri. Hasil penelitian ini untuk subjek pertama yakni AC sejalan dengan Fahrani (2014) merupakan kategori pertama yakni yang awalnya menolak namun seiring berjalannya waktu ia mampu menerima. Namun untuk subjek kedua yakni HD, hingga 6 tahun setalah ia memiliki ayah tiri belum menunjukkan penerimaan terhadap kondisinya, yang menurut penelitian Fahrani (2014) termasuk dalam kategori kedua.

Penerimaan diri menurut Sheerer (dalam Puspitasari, 2002) memiliki delapan komponen. 
Subjek AC menunjukkan ia memiliki penerimaan diri yang baik karena tujuh dari delapan komponen dimiliki oleh AC yaitu memiliki perspektif diri positif, mampu menerima kelemahan diri tanpa membenci diri sendiri, bertanggungjawab dengan tugas-tugas yang dimiliki, meyakini kemampuan dalam menjalani kehidupan, sadar dan tidak malu dengan keadaan diri, tidak mengingkari dorongan dan emosi diri dan menerima kritik secara objektif.

Sementara itu pada subjek HD hanya 4 komponen penerimaan diri dari 8 komponen yaitu menerima diri sendiri dan orang lain meskipun untuk menerima diri terkait keluarga tirinya ia belum mampu tetapi untuk orang lain selain keluarga tiri ia bisa menerima. Selanjutnya ia bisa menerima masukan tersebut meskipun kadang menunjukkan penolakan secara langsung saat diberikan. la juga mengenali kelebihan dan kekurangan yang dimilikinya namun sangat minimal, karena ia hanya mampu mengungkapkan minatnya tanpa memiliki kelebihan dalam bidang tersebut. Selanjutnya HD memiliki sikap yang terbuka, yakni ia dengan terang-terangan mengungkapkan baik kekurangan, maupun minatnya, bahkan perilaku penolakan yang didapatkannya dari ayah tirinya. Subjek HD dapat disimpulkan kurang mampu memiliki penerimaan diri. Hal yang membedakan kedua subjek adalah kemampuan untuk berpikir positif dan mengambil hikmah serta kemampuan mengontrol emosi. Subjek AC memiliki dua hal tersebut sedangkan HD kurang mampu dalam dua hal tersebut.

Adapun faktor-faktor yang ditemukan berperan dalam memunculkan penerimaan diri dalam penelitian ini adalah usia dan jenis kelamin. Sejalan dengan Allport (Hjelle \& Zgelle, 1992) penerimaan diri dipengaruhi oleh usia ataupun kematangan individu, dimana orang yang matang memiliki gambaran yang positif tentang dirinya sendiri dan dapat menoleransi frustasi serta dapat menerima dengan baik kelemahan yang dimiliki, selain itu orang yang matang juga bisa mengendalikan emosi mereka.

Terkait dengan faktor jenis kelamin yang pada penelitian ini subjek laki-laki kurang mampu menerima diri, sejalan dengan Hurlock (1973). la menegaskan bahwa remaja akan lebih cenderung menolak dirinya daripada menerima dirinya terutama pada remaja laki-laki yang masih menginjak masa awal remaja dimana penolakan terhadap dirinya tersebut ditandai dengan beberapa perilaku dimana remaja tidak menyukai dirinya, bahkan memandang rendah dirinya sendiri serta ia tidak mempercayai kemampuan yang dimilikinya sendiri. Penolakan terhadap diri sendiri yang dilakukan oleh remaja tersebut kebanyakan disebabkan oleh factor perbedaan yang besar antara real self dan ideal self remaja tersebut. Efek dari penolakan diri remaja adalah mereka kesulitan dalam penyesuaian diri, terdapat dua jenis gangguan kepribadian yang diakibatkan oleh penolakan diri remaja, yakni perilaku yang berfokus pada kepuasan diri namun mendapat penolakan dari lingkungan, sementara yang kedua adalah tidak puas terhadap diri sendiri namun mendapat penerimaan dari lingkungan. Tidak adanya kemampuan untuk menerima diri tanpa syarat dapat pula menyebabkan berbagai kesulitan emosi, termasuk kemarahan yang tidak terkendali.

Hurlock (1976) mengungkapkan 11 faktor penunjang penerimaan diri. Faktor-faktor penunjang penerimaan diri yang ditemukan pada kedua subjek adalah adanya harapan yang realistis tentang masa depan. AC mengungkapkan harapannya untuk dapat menjadi seorang arsitek dan berharap hubungannya bisa lebih baik dengan keluarga baik yang tiri ataupun yang keluarga kandungnya. Serupa dengan AC, HD memiliki pula harapan untuk masa depannya untuk menjadi komikus serta berharap ia bisa tinggal dengan ibu dan kakak kandungnya. Meskipun demikian mereka masih menghadapi tantangan apakah harapan-harapan tersebut akan terwujud di kemudian hari, sehingga akan berpengaruh pada penerimaan diri mereka nantinya di masa depan. Hurlock (1992) menegaskan bahwasannya ketika terjadi kesenjangan antara real self dengan ideal self seseorang dapat menurunkan tingkat harapannya sehingga mungkin untuk dicapai, sementara itu apabila seseorang tetap mempertahankan harapannya dan kesenjangan antara harapan dan kenyataan semakin besar maka kemungkinan orang tersebut menolak dirinya juga meningkat.

Faktor lain penunjang penerimaan diri adalah keberhasilan atau kesuksesan. Meski kedua subjek tidak menyampaikan banyak keberhasilan yang ada dalam hidup mereka namun keduanya cukup bangga dengan keberhasilan-keberhasilan yang telah mereka raih. $\mathrm{HD}$ dan $\mathrm{AC}$ juga sama-sama mengenal siapa diri mereka dengan mengenali kelebihan, kekurangan dan juga minat mereka. Hal itu sejalan dengan hasil penelitian yang dilakukan oleh Handayani dkk (Handayani, 1998) bahwa pengenalan diri dapat meningkatkan penerimaan diri individu.

Faktor penerimaan diri lainnya yang adalah pada subjek AC dan HD tidak menghadapi stress yang sangat 
berat sehingga meski mereka mengalami penolakan dari keluarga tiri, mereka tetap memiliki penerimaan diri sekalipun untuk subjek HD penerimaan dirinya cenderung kurang. Subjek HD memperoleh faktor penguat lain ketika ia menghadapi penolakan yaitu dukungan sosial dari keluarga asuhnya. Dukungan sosial dari keluarga asuh yang diterima oleh HD dapat membantunya dalam memunculkan penerimaan dirinya meskipun masih dalam kadar yang sedikit, sementara AC yang bahkan tidak mendapatkan dukungan sosial memilih untuk selalu berfikir positif terhadap kejadian yang menimpanya sehingga ia bisa melewati hal tersebut dengan baik. Hurlock (1976) tidak secara langsung menyebutkan dukungan sosial sebagai faktor penunjang penerimaan diri, namun menyebutkan faktor tidak adanya hambatan dari lingkungan. Hambatan dari lingkungan keluarga tiri dihadapi oleh HD namun sebagai gantinya ia memperoleh dukungan dari keluarga asuh. Subjek AC dengan kemampuannya untuk berpikir positif, mengantarkannya mampu memiliki konsep diri yang positif. Sebagaimana pendapat Hurlock (1976) konsep diri positif merupakan salah satu faktor penerimaan diri.

\section{DAFTAR PUSTAKA}

Ariyani. (2015). Hubungan orangtua-anak, penerimaan diri dan keputusasaan pada remaja dari keluarga broken home. Jurnal sains dan praktik psikologi volume 3 (1), 80-90.

Cole, Kelly. (2004). When The Wings Have Broken: The Impact Parents Divorce to Children, diterjemahkan oleh Tisa Adiantari, SS., dengan judul Mendampingi Anak Menghadapi Perceraian Orang Tua. Jakarta: Pt. Prestasi Pustakarya

Fahrani, R. (2014). Penerimaan Diri Remaja yang Memiliki Ibu Tiri. Skripsi (dipublikasikan). Universitan Islam Negeri Sultan Syarif Kasim, Pekanbaru. Diakses dari http://repository. uin-suska.ac.id/1010/

Hall, C.S., \& Lindzey, G. (1985). Introduction to Theories of Personality. Singapore: John Wiley \& Sons, Inc.

Handayani, M. dkk. (1998). Efektifitas pelatihan Pengenalan Diri terhadap Peningkatakn Penerimaan Diri dan Harga Diri. Jurnal Psikologi, No. 2 (47-55). Diakses dari http:// www.jurnal.psikologi.ugm.ac.id

Hjelle, L.A. \& Ziegler D.J. (1992). Personality Theories Basic Assumptions, Research, and

\section{KESIMPULAN}

Berdasarkan hasil penelitian yang telah dilakukan maka dapat disimpulkan bahwa Penerimaan diri bukanlah hal yang mudah dapat dilakukan oleh remaja, terutama remaja yang memiliki keluarga tiri. AC membutuhkan waktu setidaknya 3 tahun dari 10 tahun kebersamaannya dengan keluarga tiri untuk dapat menerima kondisinya yang ditolak oleh keluarga tirinya. Sementara itu HD belum mampu menerima secara lapang penolakan yang didapatkannya dari ayah tiri dan ibu kandungnya selama 6 tahun. Upaya pencapaian penerimaan diri remaja yang memiliki keluarga tiri dipengaruhi oleh faktor dukungan sosial, berfikir positif, pemahaman diri, wawasan sosial, konsep diri yang positif, keberhasilan, harapan realistis, dan juga usia atau kematangan individu. Sementara komponen terbesar yang mempengaruhi penerimaan diri remaja yang memiliki keluarga tiri adalah tidak adanya stress emosi yang berat serta mendapatkan dukungan sosial.

Applications, Third Edition. Singapore: McGraw-Hill.

Hurlock, E.B. (1973). Adolescent Development, Fourth Edition. Tokyo: McGraw-Hill Inc.

Hurlock, B. Elizabeth. (1978). Child Development Sixth Edition diterjemahkan oleh dr. Med. Meitasari Tjandrasa dengan judul Perkembangan Anak Jilid 2. Jakarta: Erlangga.

Hurlock, B. Elizabeth. (1980). Development Psychology, A Life-Span Approach, Fifth Edition diterjemahkan oleh Dra. Istiwidayanti dan Drs. Soedjarwo, M.Sc dengan judul Psikologi Perkembangan, Suatu Pendekatan Sepanjang Rentang Kehidupan, Edisi Kelima. Jakarta: Erlangga.

Hurlock, Elizabeth B. (1976). Personality Development. New Delhi: Tata McGraw-Hill Publishing Company LTD.

Jersild, A. T., Brook, J. S., \& Brook, D. W. (1978). The Psychology of Adolescence, $3^{\text {rd }}$ Edition. New York: Macmillan Publishing Co., Inc.

Kubler-Ross. (1998). On Death and Dying (Kematian sebagai bagian dari kehidupan). Jakarta: PT Gramedia Pustaka Utama 
Notosoedirdjo, M. \& Latipun. (2007). Kesehatan Mental. Malang: Penerbitan Universitas Muhammadiyah Malang.

Reber, Arthur S. (2012). The Penguin Dictionary of Psychology diterjemahkan oleh Yudi Santoso, S.Fil dengan judul Kamus Psikologi. Yogyakarta: Pustaka Pelajar.

Santrock, John W. (2007). Adolesence, eleventh edition, diterjemahkan oleh Benedictine
Widyasinta dengan judul Remaja, edisi 11, jilid 2. Jakarta: Erlangga.

Schultz. (1991). Psikologi Pertumbuhan. Yogyakarta: Kanisius

Silalahi, Karlinawati. \& Eko A. Meinarno. (2010). Keluarga Indonesia: Aspek dan Dinamika Zaman. Jakarta: PT. Rajagrafindo Persada.

Sugiyono. 2011. Metode Penelitian Kuantitatif Kualitatif dan R\&D. Bandung: Alfabeta 